\title{
Az oxidatív stressz szerepe szívelégtelenségben
}

\author{
Gál Roland dr. - Halmosi Róbert dr.
}

Pécsi Tudományegyetem, Általános Orvostudományi Kar, Klinikai Központ, I. Belgyógyászati Klinika, Pécs

\begin{abstract}
Az oxidatív stressz fontos szerepet játszik a szívelégtelenség kialakulásában. A szívizomzatban megtalálható összes sejttípus részt vesz az oxigén- és a nitrogén-szabadgyökök termelésében. A reaktívoxigén-származékok potenciális forrásának a szívben a NADPH-oxidáz, a nitrogén-oxid-szintázok, a lipoxigenázok, a ciklooxigenázok, a xantinoxidáz, a citokróm P450 enzimek, illetve a mitokondriális légzési lánc elemei tekinthetők. A reaktívoxigén-származékok okozta károsodás magában foglalja mind a vascularis rendszer (endotheldiszfunkció, atherosclerosis), mind a myocardium direkt károsodását (bal kamrai remodelling). A reaktívoxigén-származékok sejtszinten fehérje-, lipid- és DNSkárosodáshoz, valamint számos jelátviteli út modifikációjához vezetnek, amelyek központi szerepet töltenek be a remodelling, a hypertrophia és a kamrai dilatatio kialakulásában. Orv. Hetil., 2015, 156(47), 1916-1920.
\end{abstract}

Kulcsszavak: oxidatív stressz, reaktívoxigén-származékok, remodelling, szívelégtelenség

\section{The role of oxidative stress in heart failure}

Oxidative stress plays an important role in the development of heart failure. Reactive oxygen and nitrogen species can be generated in all cell types that can be found in the myocardium. Potential sources of reactive oxygen species are the NADPH oxidases, nitric oxide synthase, lipoxygenases, cyclooxygenase, xanthine oxidase, cytochrome P450 enzymes, and the mitochondrial respiratory chain. The reactive oxygen species mediated damages are implicated in both the vascular system (endothelial dysfunction, atherosclerosis) and the myocardium (remodeling). Oixidative stress causes lipid and protein oixidation as well as single stranded DNA breaks and induces changes in signaling pathways which serve as central transducers of cardiac hypertrophic growth, remodeling and/or ventricular dilatation.

Keywords: oxidative stress, reactive oxygen species, remodeling, heart failure

Gál, R., Halmosi, R. [The role of oxidative stress in heart failure]. Orv. Hetil., 2015, 156(47), 1916-1920.

(Beérkezett: 2015. augusztus 18; elfogadva: 2015. szeptember 23.)

\section{Rövidítések}

Akt-1/GSK-3 $\beta$ = glikogénszintáz-kináz-3 $\beta$; CaMKII = kalcium-kalmodulin-kináz II; COX = ciklooxigenáz; eNOS = endothelialis NOS; ERK $1 / 2$ = extracellular signal-regulated protein kinase $1 / 2$; ESR = elektronspin-rezonancia; $\mathrm{JNK}=$ c-Jun NH2-terminális kináz; NO = nitrogén-monoxid; NOS = nitrogén-oxid-szintáz; p38-MAPK = p38 mitogénaktivált fehérjekináz; PARP-1 = poli $(\mathrm{ADP}-$ ribóz $)$ polimeráz-1; $\mathrm{PKC}=$ proteinkináz $\mathrm{C}$; ROS $=($ reactive oxygen species $)$ reaktívoxigén-származékok

Az oxidatív stressz a reaktívoxigén- vagy nitrogéneredetû szabad gyökök keletkezése és az antioxidáns védőrendszerek közötti egyensúly megbomlása, a sejtek oxi- doredukciós állapotának megváltozása során lép fel, amikor a redoxállapot az oxidáció irányába tolódik el. Az oxidatív stressz következtében a sejtek szinte mindegyik biomolekulája sérülhet [1]. Nem meglepő ezért, hogy a szabad gyökös károsodások fontos patogenetikai tényezők a legtöbb betegség kialakulásában. Így van ez a szívér rendszeri betegségek és a szívelégtelenség esetén is.

A szívelégtelenség a szív olyan funkcionális vagy strukturális károsodása, amely elégtelenné teszi a szív szöveti igényeknek megfelelő oxigénszállítását. A szívelégtelenség prevalenciája folyamatosan emelkedik - a kardiológiai kórképek közül egyedüliként. A fejlett országokban a felnőtt lakosság 1\%-át érinti, de 70 év felett a prevalencia már eléri a $10 \%$-ot. Kialakulásában a legfon- 
tosabb rizikótényezőnek a hypertonia és a koszorúér-betegség tekinthető [2]. A szívelégtelenségnek klinikailag széles a spektruma, kezdve az aszimptomatikus balkamra-hypertrophiától egészen a manifeszt betegségig (diasztolés vagy szisztolés szívelégtelenség). A legtöbb esetben a károsító behatásokra (például hypoxia, volumenterhelés) a szív adaptációs mechanizmusok beindításával válaszol, ami kardiális remodellinghez, hypertrophiához vezet.

A remodelling szövettanilag a szívizomsejtek megvastagodásával, valamint az interstitialis kötőszövet mennyiségének jelentős megnövekedésével jellemezhető [3]. Ennek hátterében a RAAS-rendszer, a szimpatikus idegrendszer és az ezek következtében megváltozott intracelluláris jelátviteli mechanizmusok állnak [4].

\section{ROS és szívelégtelenség}

Az elmúlt évtizedekben kísérletes és klinikai vizsgálatok sora igazolta a reaktívoxigén-származékok (ROS) kiemelkedő szerepét a szívelégtelenség kialakulásában. Az oxigén-szabadgyökök direkt módon károsítják a kontraktilitást, továbbá a hypertrophiában szerepet játszó jelátviteli és transzkripciós faktorok aktivitására is jelentős hatással bírnak, fokozzák az apoptózist. Emellett növelik a fibroblastok proliferációját és aktiválják a mátrixmetalloproteinázokat. Mindezek a mechanizmusok szintén maladaptív hypertrophiához és szívelégtelenséghez vezetnek [5].

Számos vizsgálatban igazolták a ROS fokozott képződését a károsodott szívizomban [6]. Ennek kimutatására alkalmazott elektronspin-rezonanciás (ESR) spektroszkópiás vizsgálatok direkt bizonyítékot nyújtottak az elégtelenül múködő szívben a fokozott mennyiségű oxigén-szabadgyök jelenlétére [7].

Mint korábban említettük, a ROS és az antioxidánsrendszer közötti egyensúly felborulása oxidatív stressz kialakulásához vezet. Mivel az antioxidáns enzimek mennyisége érdemben nem változik szívelégtelenségben, sőt a GPx aktivitása még fokozódik is, ezért egyértelműen a megnövekedett szabadgyök-produkció felelős az oxidatív stressz kialakulásáért, nem pedig a csökkent antioxidáns védelem [8].

\section{A ROS forrásai szívelégtelenségben}

A szabad gyökök a szívizom szinte minden sejtjében képződhetnek, így a cardiomyocytákban, az endothelialis sejtekben és fehérvérsejtekben egyaránt. A szívizomsejtekben elsősorban a mitokondriumok tekinthetők a legfontosabb szabadgyök-forrásnak, de szerepe van a NADPH-oxidáznak (NOX-izoformák), a xantinoxidáznak, valamint a szétkapcsolt nitrogén-oxid-szintázoknak (NOS) is [9].

Fiziológiás körülmények között az esetek 98\%-ában ATP termelődik a mitokondriumokban a mitokondriális légzési lánc enzimei által, míg mindössze 1-2\%-ban ROS is képződik, azonban ezt a mennyiségű oxidánst könnyedén semlegesítik az endogén scavenger mechanizmusok (például SOD). Ha azonban a mitokondrium légzési aktivitását blokkolják a komplex-I és komplex-III szintjén, akkor jelentősen megemelkedik a mitokondriumban keletkezett szuperoxid anionok mennyisége [9]. A fenti jelenség mellett szívelégtelenség esetén jelentősen csökken a légzési láncban szereplő komplexek aktivitása is [10]. A mitokondriumok funkciójának károsodása (megfelelő mennyiségű NADPH jelenlétében) lehet felelős az oxigénszabadgyök-produkció megemelkedéséért [10].

A NADPH-oxidázok azáltal termelnek szuperoxid aniont $\left(\mathrm{O}_{2}^{-}\right)$, hogy egy elektrontranszfert hajtanak végre a felszínükön lévő NOX segítségével a NADPH-ról a molekuláris oxigénre. A NOX-ok 5 izoformája közül a szívben a 2 -es és a 4 -es játszik jelentős szerepet. A NADPH-oxidázt számos olyan faktor aktiválja, amely a szívelégtelenség patogenezisében is esszenciális szerepet játszik. Ilyen például a mechanikai feszülés, angiotenzinII, endothelin-I és a tumornekrózis-faktor- $\alpha$. A NOX-4 egy mitokondriumban található izoforma, amely esetén igazolták, hogy a bal kamrai nyomásterhelés és az öregedés hatására különösen fokozódik az aktivációja [11, $12]$.

A xantinoxidáz szintén jelentős ROS-forrásnak tekinthető. Állatkísérletekben kimutatták, hogy a xantinoxidáz-gátló allopurinol kedvező hatást fejt ki szívelégtelenségben, mivel fokozza a kontraktilitást, illetve mérsékli a szívizom posztinfarktusos remodellingjét [13].

A szétkapcsolt NOS szabadgyök-képző potenciálja is jól ismert, amelyben elsősorban a NOS-3-nak (eNOS endothelialis NOS) van komoly szerepe. Fiziológiásan az eNOS NADPH felhasználásával L-argininból és $\mathrm{O}_{2}$-ból NO-ot és L-citrulint képez. Azonban oxidatív stressz hatására, amennyiben a NOS-kofaktor tetrahidrobiopterin $\left(\mathrm{BH}_{4}\right)$ mennyisége is csökken, akkor a NOS szétkapcsol, ilyenkor strukturálisan instabillá válik, NO helyett ROS-t kezd el termelni [14].

$\mathrm{Az}$ endothelsejtekben a reaktívoxigén-szabadgyökök forrása elsősorban a NADPH-oxidáz és a xantinoxidázok. A szívizomzatban lévő fehérvérsejtek is szerepet játszhatnak a ROS-képzésben. Ez a megállapítás azokon az eredményeken alapul, hogy a leukocytákban termelt mieloperoxidáz (MPO) plazmakoncentrációja egyenesen arányos a szívelégtelenség súlyosságával, sőt jól jelzi a beteg prognózisát is [15].

\section{A ROS következményei szivelégtelenségben}

Amint már említettük, a mitokondriumok fontos szabadgyök-forrásnak tekinthetőek, emellett azonban a ROS káros következményeinek egyik kulcsfontosságú struktúrái is, mivel a szabad gyökök - köszönhetően az igen rövid fél életidejüknek - a termelődés helyén, illetve ahhoz nagyon közel képesek csak károsodást kiváltani. Mitokondriális szinten a károsodás elsősorban a membránt, a légzési lánc elemeit, a mitokondriális DNS-t, illet- 
ve a transzkripciós faktorokat érinti (1. ábra). Mint ismeretes, a mitokondriumoknak saját örökítőanyaguk (kettős láncú cirkuláris DNS) van, amely a légzési lánc komplexeinek genetikai állományát kódolja [16]. Az mtDNS számos tényező miatt különösen sérülékeny és az egyik fó targetje a mitokondriumban a patológiás mennyiségben termelődött szabad gyököknek. Elsőként kiemelendő, hogy a mitokondrium nem rendelkezik komplex kromatinstruktúrával, például hisztonokkal, amelyek hatásos barriert képeznének a ROS-sal szemben. Másodsorban az mtDNS-nek jóval gyengébb a repair aktivitása. Végül a képződött szuperoxidgyökök jelentős hányada nem képes a mitokondriális membránon át kijutni a citoplazmába, így a károsodást a mitokondriumon belül idézik elő [17].

A DNS-sérülés következtében károsodik a mitokondriálisfehérje-expresszió, így a légzési lánc komplexeinek mennyisége is csökkenni fog, amely összességében a mitokondrium funkcióvesztését, tehát energiadepléciót idéz elő. Szívelégtelenségben is igazolták a mitokondrium károsodását és diszfunkcióját, amelyet csökkent mtDNS-mennyiség, a lipidek peroxidációja, a transzkriptumok mennyiségének csökkenése és a sérült oxidatív kapacitás is jellemzett [18]. Ördögi körként a károsodott mitokondriumok aztán tovább fokozzák a ROS-termelődést, amelynek extramitokondriális következményei is lesznek (1.ábra). Nem meglepő módon jelenleg egyértelműen központi jelentőségűnek tartják a mitokondriumok károsodását a szívelégtelenség legtöbb formájában.

A ROS továbbá számos intracelluláris molekula modulálása, valamint jelátviteli utak módosítása révén fejti ki strukturálisan és funkcionálisan sejtkárosító hatását (2. ábra). A ROS hatására, stresszre adott válaszként, aktiválódó jelátviteli utak központi szerepet játszanak a szívizom-remodelling, hypertrophia kialakulásában.

$\mathrm{Az}$ oxigén-szabadgyökök direkt módon fokozzák a hypertrophiáért felelős jelátviteli utak és transzkripciós faktorok aktivitását. A sejtfelszíni GPCR- (G-proteincoupled receptor) agonisták, mint például az AT-II, az ET-1, az izoproterenol, alfa-adrenerg-agonisták ROS- mediáltan a szívizomsejt remodellingjét, hypertrophiáját idézik elő adaptációs, úgynevezett stresszválaszként számos jelátviteli úton keresztül, amelyek közül a legfontosabbak az ERKl/2 (extracellular signal-regulated protein kinases) aktiválása, a p38 mitogénaktivált fehérjekinázok (p38-MAPK), a JNK (c-Jun NH2-terminal kinases), számos proteinkináz $\mathrm{C}$ (PKC) izoforma aktiválása, valamint az Akt-1/GSK-3 $\beta$ (glycogen synthase kinase-3 $\beta$ ) jelátviteli út gátlása. A fenti jelátviteli utak nukleárisan az NF- $\kappa \mathrm{B}$ aktiválása révén már közvetlenül a génexpressziót befolyásolják. Az angiotenzin-II-stimulus, továbbá a kalcium-kalmodulin-kináz II (CaMKII) ROS-függő aktiválásán keresztül szintén a szívizomsejtek károsodásához vezet $[19,20]$. A bal kamrai nyomásterhelésre és GPCR-agonistákra adott celluláris válaszreakcióban a korábban említett NOX-2 és NOX-4 szerepét is ki kell emelni, amelyek tovább fokozzák az intracelluláris és intramitokondriális $\mathrm{O}_{2}$ és a $\mathrm{H}_{2} \mathrm{O}_{2}$ termelődését, ezzel felerősítik a fentebb említett ROS mediálta utakat.

További fontos szabadgyök-hatásként említenénk, hogy gátolják a hiszton-deacetiláz-III, a SIRT1-3-deacetilázt, amelyeknek alapvető szerepe van az NF- $\kappa \mathrm{B} / \mathrm{Bcl}-$ 2/Bax jelátvitel út leszabályozásában [21].

Az oxidatív stressz emellett DNS-károsodásokat okozva aktiválja a poli(ADP-ribóz) polimeráz-1 (PARP-1) enzimet is. A PARP-1 nagy mennyiségben található meg a sejtmagban, és egy kezdetleges DNS-repair funkciója van. Jelentős aktivációja azonban nem a sejt túlélését, hanem programozott vagy nekrotikus sejthalált okoz azáltal, hogy jelentős mennyiségü $\mathrm{NAD}^{+}$-ot és ATP-t használ fel múködéséhez. A sejt magas energiájú foszfátkoncentrációjának esése pedig a sejt diszfunkcióját és végül sejthalált okoz. A PARP-1-aktiváció emellett direkt mitokondriális hatással is bír, jelentősen rontja a légzési lánc tagjainak aktivitását, növelve ezzel a mitokondriális szabadgyök-produkciót. Az NF- $\kappa \mathrm{B}$ aktiválásával fokozza a gyulladásos faktorok termelődését, valamint a hypertrophia és a fibrosis kialakulásában szerepet játszó jelátviteli faktorok aktivitását (PKC $\alpha / \beta, \operatorname{PKC} \lambda / \zeta$, MAPKs). Továbbá a szabad gyökök csökkentik a prosurvival jelát-

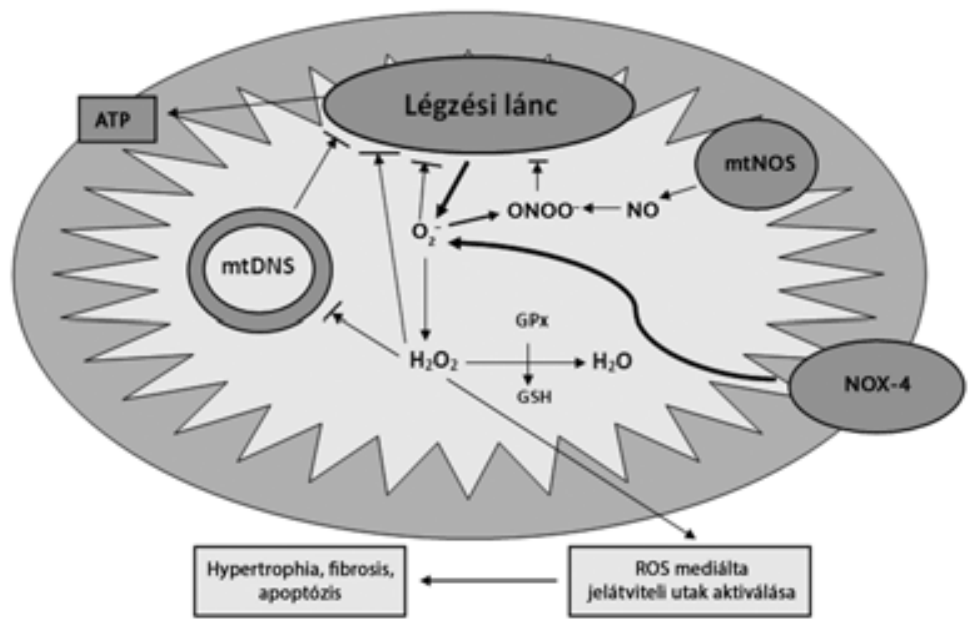

1. ábra $\quad$ A ROS mitokondriális forrásai és hatásai 


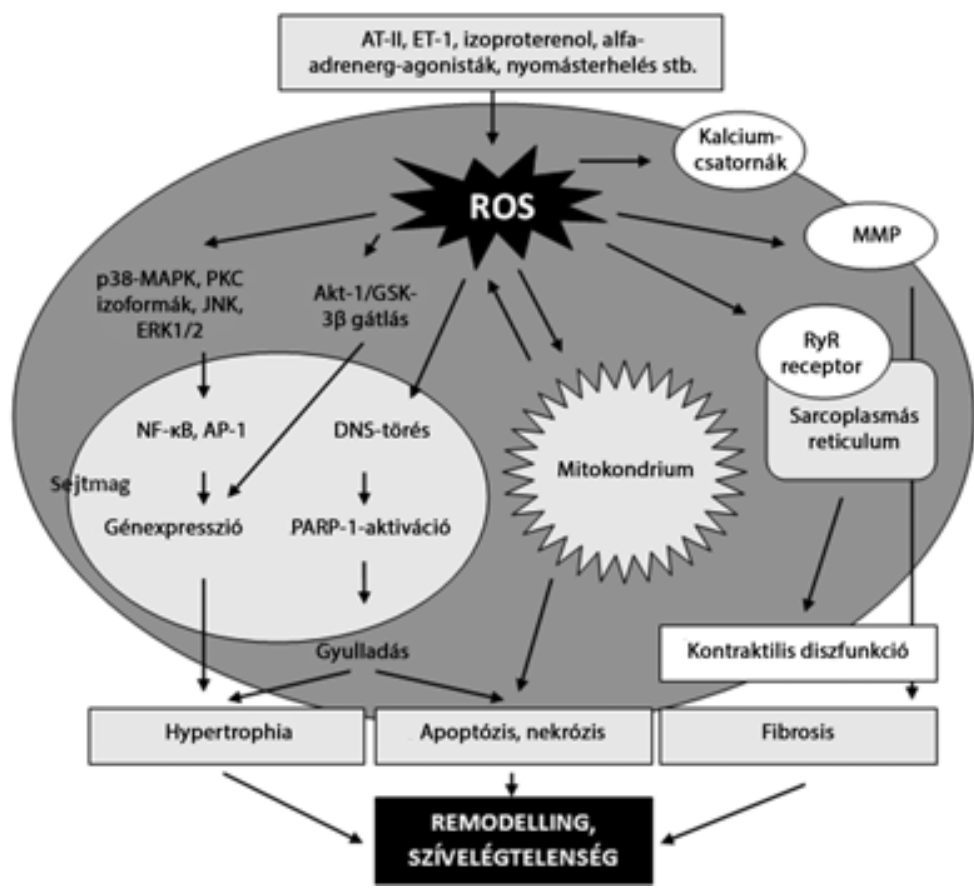

viteli faktorok aktivitását (Akt-1/GSK-3 $\beta$ ) is [22, 23]. A ROS hatására aktiválódó (redox signal pathways) jelátviteli utak a sejtek diszfunkciója mellett végsô soron fontos szerepet töltenek be a programozott sejthalál, az apoptózis kialakulásában is, amely szervszinten a szívelégtelenség progressziójához vezet.

A szabad gyököknek direkt hatásuk is van a kontraktilis funkcióra azáltal, hogy módosítják a kontrakcióban szerepet játszó fehérjéket, ezáltal csökkentve azok funkcióját. A ROS a kontraktilitást főként a sarcoplasmás reticulumban bekövetkezett változások révén befolyásolja. A NOX-2 a ryanodine receptorokhoz (RyR2) közel helyezkedik, amelyek szerepe a kalciumfelszabadulás szabályozásában van. Stressz hatására fokozódik a kalciumfelszabadulás a sarcoplasmás reticulumból, ezáltal kezdetben fokozódik a kontraktilitás, azonban hosszú távon a folyamat a kalciumraktárak kiürüléséhez, ezáltal a kontraktilitás romlásához, valamint a citoplazmatikus kalciumszint megemelkedésével fokozott aritmiahajlamhoz vezet [24].

A szabad gyökök aktiválják továbbá a mátrixmetalloproteinázokat (MMP), amelyek fontos szerepet töltenek be a remodelling és a fibrosis folyamatában, illetve végső soron a bal kamrai dilatatio és a szisztolés funkciózavar kialakulásában is [25].

A nitrogén-monoxid ( $\mathrm{NO}$ ) coronariavasodilatator, thrombocytaaggregáció-gátló, valamint a kontraktilitásra kifejtett hatásán keresztül fiziológiásan pozitív szabályozó szereppel bír. Az említett reguláció mediálásában a szolúbilis guanil-cikláz központi szerepet kap, amely az intracellulláris $\mathrm{Ca}^{2+}$-szint csökkentésével az oxidatív stressz gátlását idézi elő [1]. Azonban a rendszerbe kerülő szuperoxidgyök $\left(\cdot \mathrm{O}_{2}^{-}\right)$a $\mathrm{NO}$-dal reakcióba lépve egy- részt inaktiválja azt, másrészt egy jóval reaktívabb gyököt, a peroxinitritet $\left(\cdot \mathrm{ONOO}^{-}\right)$hozza létre. Emellett állatkísérletek igazolták, hogy a szétkapcsolt eNOS és az alacsony $\mathrm{BH}_{4}$ - (tetrahidrobiopterin-) szint fokozza a kardiális remodelling és hypertrophia kialakulását krónikus nyomásterhelés (aortaszúkítés) hatására [26].

A szívizomsejtek hypertrophiája, diszfunkciója, apoptózisa mellett a szívelégtelenség kialakulásában az interstitialis fibrosisnak is kulcsszerepe van. A ROS-függő jelátviteli utak a kardiális fibrosis kialakulásában is döntő befolyással bírnak. Az angiotenzin-II indukálta fibroblastproliferációban a NOX-2-aktivációt és JNK/NF«B-AT-1 jelátviteli út modulálását találták, míg a NOX4-nek a TGF- $\beta$ aktiválta Smad $2 / 3$ jelátviteli útnak tulajdonítanak szerepet [27].

\section{Következtetések}

Összefoglalva elmondható tehát, hogy a reaktívoxigén(és nitrogén-) szabadgyökök központi szerepet játszanak, számos egyéb betegséghez hasonlóan, a szívelégtelenség kialakulásában és progressziójában egyaránt. Az oxidatív stressz számos módon mérsékelhető, logikusan a legegyszerúbbnek a scavenger molekulák alkalmazása tûnhet, azonban noha e molekulák egyszerû kísérletes körülmények között kifejezett pozitív hatással bírnak [28], azonban az összetett klinikai körülmények között nem javították a betegek túlélését. Emiatt az utóbbi évtizedben új terápiás lehetőségek keresése felé fordultak a kutatólaboratóriumok. Jelenleg a szabad gyökös károsodás által okozott circulus vitiosusok kivédésére igyekszünk koncentrálni. Két ilyen fontos pont a sejt energiatermelő központja, a mitokondrium, illetve a PARP-1 
enzim aktivációja. Ígéretes kutatások folynak farmakológiai PARP-gátlókkal különféle kísérletes szívelégtelenség-modellekben, amelyek szerteágazó pozitív hatással bírnak a jelátviteli és transzkripciós faktorok aktivitására, illetve megőrzi a szívizomzat strukturális és funkcionális integritását. E vizsgálatok eredményeinek következtében talán hamarosan a szívelégtelenség mindennapos kezelésében is szerepet kaphatnak a PARP-gátlók [29, 30].

Anyagi támogatás: A közlemény megírása anyagi támogatásban nem részesült.

Szerzői munkamegosztás: G. R.: A kézirat összeállítása. H. R.: A kézirat javítása, szakmai felügyelet. A cikk végleges változatát mindkét szerző elolvasta és jóváhagyta.

Érdekeltségek: A szerzőknek nincsenek érdekeltségeik.

\section{Irodalom}

[1] Tsutsui, H., Kinugawa, S., Matsushima, S.: Oxidative stress and heart failure. Am. J. Physiol. Heart Circ. Physiol., 2011, 301(6), H2181-H2190.

[2] McMurray, J. J., Adamopoulos, S., Anker, S. D. et al.: ESC Guidelines for the diagnosis and treatment of acute and chronic heart failure 2012. The Task Force for the Diagnosis and Treatment of Acute and Chronic Heart Failure 2012 of the European Society of Cardiology. Developed in collaboration with the Heart Failure Association (HFA) of the ESC. Eur. Heart J., 2012, 33(14), 1787-1847.

[3] Pfeffer, J. M., Pfeffer, M. A., Fletcher, P. J., et al.: Progressive ventricular remodeling in rat with myocardial infarction. Am. J. Physiol. Heart Circ. Physiol., 1991, 260(5), H1406-H1414.

[4] Gajarsa, J. J., Kloner, R. A.: Left ventricular remodeling in the post-infarction heart: a review of cellular, molecular mechanisms, and therapeutic modalities. Heart Fail. Rev., 2011, 16(1), 1321.

[5] Takimoto, E., Kass, D. A.: Role of oxidative stress in cardiac hypertrophy and remodeling. Hypertension, 2007, 49(2), 241248.

[6] Hill, M. F., Singal, P. K.: Antioxidant and oxidative stress changes during heart failure subsequent to myocardial infarction in rats. Am. J. Pathol., 1996, 148(1), 291-300.

[7] Ide, T., Tsutsui, H., Kinugawa, S., et al.: Direct evidence for increased hydroxyl radicals originating from superoxide in the failing myocardium. Circ. Res., 2000, 86(2), 152-157.

[8] Tsutsui, H., Ide, T., Hayashidani, S., et al.: Greater susceptibility of failing cardiac myocytes to oxygen free radical-mediated injury. Cardiovasc. Res., 2001, 49(1), 103-109.

[9] Ide, T., Tsutsui, H., Kinugawa, S., et al.: Mitochondrial electron transport complex I is a potential source of oxygen free radicals in the failing myocardium. Circ. Res., 1999, 85(4), 357-363.

[10] Sawyer, D. B., Colucci, W. S.: Mitochondrial oxidative stress in heart failure: "oxygen wastage" revisited. Circ. Res., 2000, $86(2), 119-120$.

[11] Kuroda, J., Ago, T., Matsushima, S., et al.: NADPH oxidase 4 (Nox4) is a major source of oxidative stress in the failing heart. Proc. Natl. Acad. Sci. U.S.A., 2010, 107(35), 15565-15570.

[12] Heymes, C., Bendall, J. K., Ratajczak, P., et al.: Increased myocardial NADPH oxidase activity in human heart failure. J. Am. Coll. Cardiol., 2003, 41(12), 2164-2171.

[13] Mizushige, K., Yao, L., Noma, T., et al.: Alteration in left ventricular diastolic filling and accumulation of myocardial collagen at insulin-resistant prediabetic stage of a type II diabetic rat model. Circulation, 2000, 101(8), 899-907.

[14] Landmesser, U., Dikalov, S., Price, S. R., et al.: Oxidation of tetrahydrobiopterin leads to uncoupling of endothelial cell nitric oxide synthase in hypertension. J. Clin. Invest., 2003, 111(8), 1201-1209.

[15] Tang, W. H., Tong, W., Troughton, R. W., et al.: Prognostic value and echocardiographic determinants of plasma myeloperoxidase levels in chronic heart failure. J. Am. Coll. Cardiol., 2007, 49(24), 2364-2370.

[16] Clayton, D. A.: Replication and transcription of vertebrate mitochondrial DNA. Annu. Rev. Cell Biol., 1991, 7, 453-478.

[17] Giulivi, C., Boveris, A., Cadenas, E.: Hydroxyl radical generation during mitochondrial electron transfer and the formation of 8-hydroxydesoxyguanosine in mitochondrial DNA. Arch. Biochem. Biophys., 1995, 316(2), 909-916.

[18] Ide, T., Tsutsui, H., Hayashidani, S., et al.: Mitochondrial DNA damage and dysfunction associated with oxidative stress in failing hearts after myocardial infarction. Circ. Res., 2001, 88(5), 529535.

[19] Baines, C. P., Molkentin, J. D.: STRESS signaling pathways that modulate cardiac myocyte apoptosis. J. Mol. Cell. Cardiol., 2005, 38(1), 47-62.

[20] Palfi, A., Toth, A., Hanto, K., et al.: PARP inhibition prevents postinfarction myocardial remodeling and heart failure via the protein kinase $\mathrm{C} / \mathrm{glycogen}$ synthase kinase- $3 \beta$ pathway. J. Mol. Cell. Cardiol., 2006, 4l(1), 149-159.

[21] Chen, C. J., Fu, Y. C., Yu, W., et al.: SIRT3 protects cardiomyocytes from oxidative stress-mediated cell death by activating NFkappaB. Biochem. Biophys. Res. Commun., 2013, 430(2), 798803.

[22] Bartha, E., Solti, I., Kereskai, L., et al.: PARP inhibition delays transition of hypertensive cardiopathy to heart failure in spontaneously hypertensive rats. Cardiovasc. Res., 2009, 83(3), 501510.

[23] Deres, L., Bartha, E., Palfi, A., et al.: PARP-inhibitor treatment prevents hypertension induced cardiac remodeling by favorable modulation of heat shock proteins, Akt-1/GSK-3 $\beta$ and several PKC isoforms. PLoS ONE, 2014, 9(7), e102148.

[24] Marks, A. R.: Cardiac intracellular calcium release channels: role in heart failure. Circ. Res., 2000, 87(1), 8-11.

[25] Spinale, F. G., Coker, M. L., Thomas, C. V., et al.: Time-dependent changes in matrix metalloproteinase activity and expression during the progression of congestive heart failure: relation to ventricular and myocyte function. Circ. Res., 1998, 82(4), 482-495.

[26] Takimoto, E., Champion, H. C., Li, M., et al.: Oxidant stress from nitric oxide synthase- 3 uncoupling stimulates cardiac pathologic remodeling from chronic pressure load. J. Clin. Invest., 2005, 115(5), 1221-1231.

[27] Cucoranu, I., Clempus, R., Dikalova, A., et al.: NAD(P)H oxidase 4 mediates transforming growth factor-betal-induced differentiation of cardiac fibroblasts into myofibroblasts. Circ. Res., 2005, 97(9), 900-907.

[28] Halmosi, R., Deres, P., Toth, A., et al.: 2,2,5,5-tetramethylpyrroline-based compounds in prevention of oxyradical-induced myocardial damage. J. Cardiovasc. Pharmacol., 2002, 40(6), 854867.

[29] Bartha, E., Kiss, G. N., Kalman, E., et al.: Effect of L-2286, a poly(ADP-ribose)polymerase inhibitor and enalapril on myocardial remodeling and heart failure. J. Cardiovasc. Pharmacol., 2008, 52(3), 253-261.

[30] Bartha, E., Solti, I., Szabo, A., et al.: Regulation of kinase cascade activation and heat shock protein expression by poly(ADP-ribose) polymerase inhibition in doxorubicin-induced heart failure. J. Cardiovasc. Pharmacol., 2011, 58(4), 380-391.

(Gál Roland dr., Pécs, Ifjúság útja 13., 7624 e-mail: gal.roland@pte.hu) 